\title{
Article \\ Facing COVID-19: Quantifying the Use of Reusable vs. Disposable Facemasks
}

\author{
Dirk H. R. Spennemann
}

check for updates

Citation: Spennemann, D.H.R. Facing COVID-19: Quantifying the Use of Reusable vs. Disposable Facemasks. Hygiene 2021, 1, 120-128. https://doi.org/10.3390/ hygiene1030011

Academic Editors: Daniela Haluza and Günter Kampf

Received: 16 October 2021

Accepted: 17 November 2021

Published: 22 November 2021

Publisher's Note: MDPI stays neutral with regard to jurisdictional claims in published maps and institutional affiliations.

Copyright: (C) 2021 by the author. Licensee MDPI, Basel, Switzerland. This article is an open access article distributed under the terms and conditions of the Creative Commons Attribution (CC BY) license (https:// creativecommons.org/licenses/by/ $4.0 /)$.
Institute for Land, Water and Society, Charles Sturt University, P.O. Box 789, Albury, NSW 2640, Australia; dspennemann@csu.edu.au

\begin{abstract}
Following the outbreak of the COVID-19 pandemic in March 2020, many governments have recommended or mandated the wearing of fitted face masks to limit the transmission of the virus via aerosols. The public had, in essence, two choices: single-use, disposable surgical masks and multi-use, washable cloth masks. While the use of cloth masks has been discussed, there are, at present no baseline data that establish the actual proportions of mask types worn in the public. This paper, which presents the findings of rapid walk-through surveys of shopping venues in Albury (Southern New South Wales, Australia), demonstrates that, overall, 33.6\% of masks worn by the public were cloth masks.
\end{abstract}

Keywords: COVID-19; personal protective equipment; face masks

\section{Introduction}

Between January and March 2020, COVID-19, the disease caused by the severe acute respiratory syndrome coronavirus 2 (SARS-CoV-2) [1], rapidly developed into a global pandemic. Measures to curb or at least slow the progress of COVID-19 were enacted by governments at each national level. Given that SARS-CoV-2 is primarily transmitted via aerosols emitted while breathing, coughing, or sneezing [2,3], many governments have recommended or mandated the wearing of fitted face masks as part of their public health initiatives [4-7].

Until the arrival of the COVID-19 pandemic, three types of face masks were common, but restricted in their use to specific professions and activities: single-use, disposable surgical masks used by the medical profession (Figure 1a); single-use, disposable P2/KN95 type masks (with and without valves) used in the construction industry to filter low levels of dust and paint fumes (Figure 1b); and full face masks with exchangeable air filters for more hazardous work [8-11]. Prior to COVID-19, face masks were worn in non-professional settings only in a number of Asian countries, a practice spurred by the SARS-CoV-1 epidemic of 2003 [12].

The high demand for face masks during the COVID-19 pandemic led to an expanded production of single-use, disposable surgical-type masks and a proliferation of washable and thus reusable face masks made from various types of fabric (Figure 1c). These were offered by major clothing retailers as well as by a cottage industry using templates provided by national drapery chains [13].

The costs of single-use surgical masks ranged, depending on vendors, from AUD 1-2 for single masks and AUS 4-10 for packs of ten (all prices in AUD). Subject to availability, boxes of 100 masks could be obtained for AUD 25-30. The prices of KN95 masks ranged from $₫ 40$ charged by a hardware chain (or AUD 4 for packs of 10) to AUD 2.95 charged by a stationery chain (all prices pers. obs. July and August 2021). Cloth masks retailed for between AUD 4-25 per piece, depending on whether they were fitted with a wire to ensure a tighter fit around the nose.

While cheaper on a per-unit basis, single-use masks are thus more economical in situations where the mandated period to wear fitted face masks is short, but become the 
more expensive option where the mask mandate is prolonged. Setting aside examples where disposable surgical masks were provided free of charge [14], other considerations taken into account by users general efficacy of one type over the other [15-17], the wearcomfort and respiration level afforded by the various types [18,19], the nature of washing reusable masks [20] and the general environmental awareness of the user. While the longterm environmental implications of single-use masks due to microplastics [21,22] are not the concern of this paper, general environmental awareness of the user influences the type of mask worn [23]. While there is evidence that single-use masks are worn for several days as well as being washed and re-used [24-27], this does not appear to be common practice in Australia.

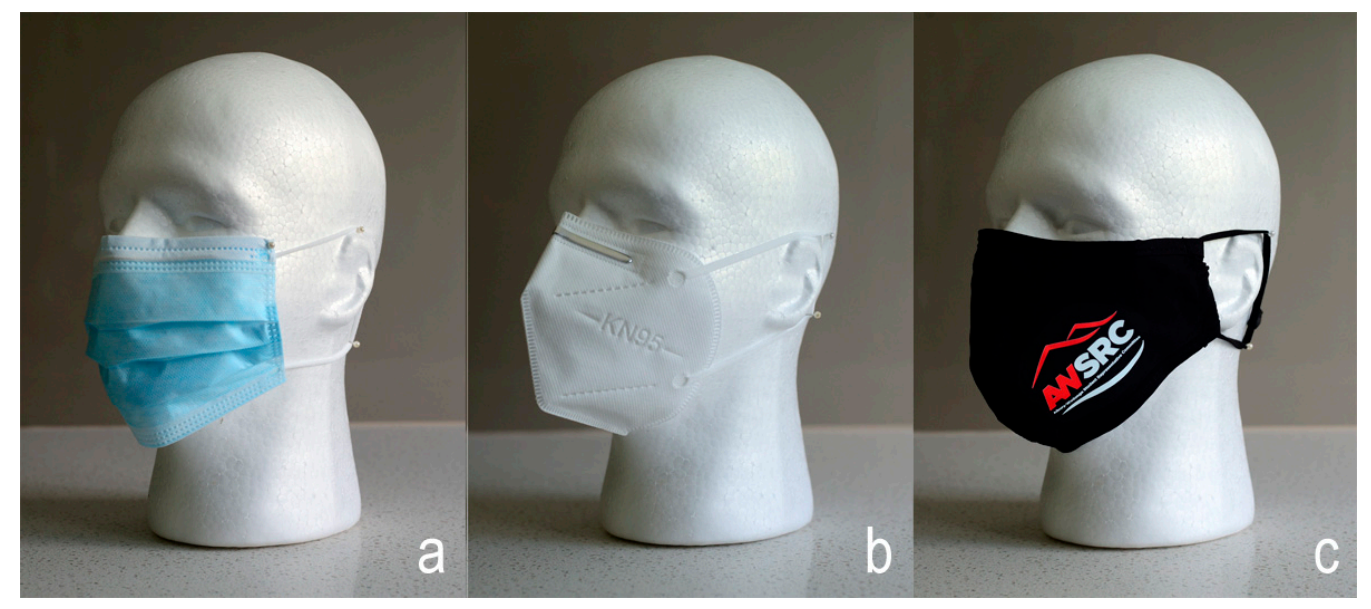

Figure 1. The three types of masks discussed in this paper. (a) surgical-type disposable mask; (b) disposable KN95 mask; (c) cloth/fabric mask.

After the delta variant of COVID-19 began to spread through the community, the New South Wales (NSW) Government-imposed conditions for the wearing of fitted face coverings (masks) for all persons over 12 years of age to all indoor settings. This occurred first in the Greater Sydney area from the 6 May $2021[28,29]$ and was extended across the entire state on 26 June 2021 [30]. The carrying of masks when outside the private home became mandatory for all people ages 12 years and older on 23 August 2021, a week after a state-wide lockdown had been declared [31]. The public health orders defined a fitted face covering as "a mask or other covering that (a) fits securely around the face, and (b) is designed or made to be worn over the nose and mouth to provide the wearer with protection against infection" [29]. While the regulations thus excluded the use of bandanas, they did not specify the material the masks were to be made of. Consequently, there were disposable masks made from thermoplastic polymers (mainly polypropylene but also polyester) and washable reusable masks from woven fabric (mainly cotton), neoprene and polypropylene [13].

As part of a wider project on the assessment and documentation of cultural heritage aspects of the COVID-19 pandemic [13,32-35], the author had been documenting the occurrence and type of discarded or lost items of personal protective equipment on the streets of Albury (NSW, Australia) since mid-November 2020 [36]. While that project noted an overwhelming prevalence of disposable, surgical-type facemasks (93.5\%) being discarded or lost compared to cloth/fabric masks, it could not establish whether these proportions were representative of the mask usage by the general population of that community.

At the time of writing, no studies specifically focused on the type of face masks worn. Some data on the prevalence of fabric masks could be extracted from other studies and include observations in Poland [37,38], Vietnam [39], Bali (Indonesia) [40], Nigeria [41], India [42], Morocco [43], and Iran [44]. None of these, however, can be extrapolated to the Australian situation given cultural differences in the observed communities. In the absence 
of prior data on the matter, there was a need to ascertain the actual relative proportions of these face masks as worn by the community. This paper reports on the findings of a series of rapid walk-through surveys designed to establish such baseline data.

\section{Materials and Methods}

The survey data were collected between 16 and 24 August 2021 in Albury, a rural service center located in Southern New South Wales (NSW), Australia, with an estimated population of 54,353 people (census 2016: 51,076) [45,46]. The survey area is comprised of central Albury, and covers two shopping centers, two stand-alone supermarkets and one office supply store in the central business district (CBD); a hardware store in an industrial estate at the eastern periphery; and one shopping center and a stand-alone supermarket in a northern suburb (Lavington) (Figure 2). Each of the shopping centers contained a supermarket which was counted separately from the public areas of the center. These foci were augmented by observations of pedestrians on the streets while driving from one location to an or the other. Each location was surveyed at least twice (Tables 1 and 2).

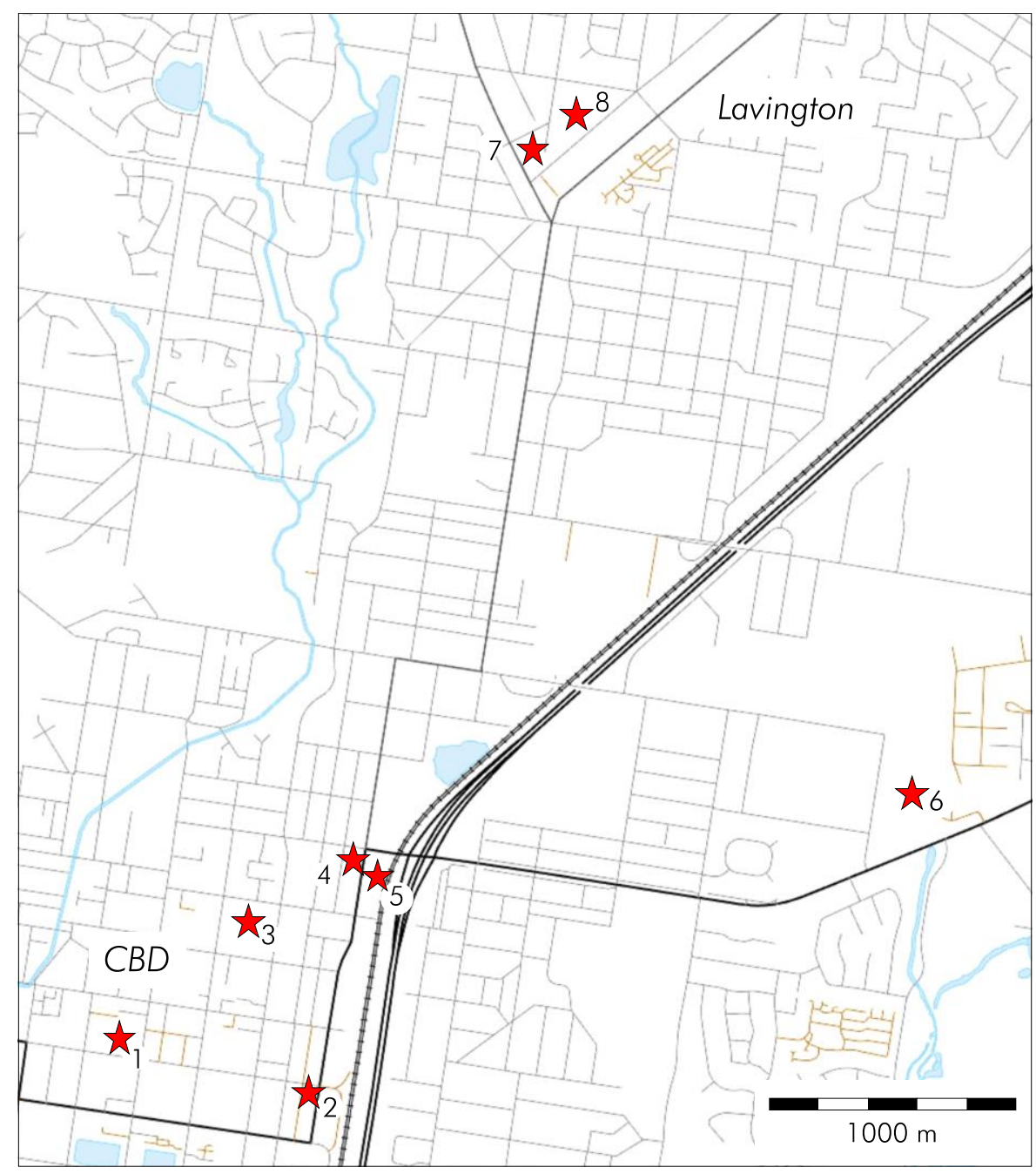

Figure 2. Map of central Albury (NSW), showing the locations mentioned in the text. (1) Westend Plaza Shopping Centre; (2) Officeworks; (3) Myer Shopping Centre; (4) Aldi Supermarket; (5) Harris Farm Supermarket; (6) Bunnings Hardware; (7) Coles Supermarket; (8) Centro Shopping Centre.

The survey design was that of a rapid, linear continuous-movement walk-through survey. To ensure consistency and internal data integrity, the data collection was carried out by a single observer (the author) with research experience in the identification of the types of masks worn $[13,36]$. The collected data were limited to observations of three readily 
identifiable types of masks worn by passers-by (surgical-type disposable, KN95 disposable, cloth fabric; Figure 1).

No demographic data (gender, age cohort) were collected given (i) the speed of the continual movement (to avoid double-counting), (ii) that gender is a social construct and relies on self-identification (e.g., male, female, non-binary, transgender) and (iii) given possible classification biases (in particular with regard to age). In supermarkets, the survey path ran from the entrance down the first aisle to the furthest part of the store, then along the end of the aisles, assessing customers in each aisle, along the last aisle back to the front of the store and then along the checkouts back to the entrance. In shopping centers, the survey path ran from one entrance in a linear fashion to the second entrance/exit. Each walkthrough took less than 5 min per supermarket/shopping center. The mode of survey reduced the risk of double counting.

The significance assessment of observed differences in proportions used the Chisquared test of the MEDCALC comparison of proportions calculator [47].

\section{Results}

In total 37 individual walk-through surveys were carried out at eight shopping locations with the masks worn by a total of 1847 persons classified (Table 1). Given an estimated adult (over 18) population of 42,670 persons [48], the survey is equivalent of $4.33 \%$ of the eligible community.

Table 1. Summary of the proportions of cloth masks encountered on the walk-trough surveys of shopping centers, supermarkets and specialty stores, assessing mask use in Albury (NSW).

\begin{tabular}{|c|c|c|c|c|c|c|}
\hline \multirow[b]{2}{*}{ Location } & \multicolumn{2}{|c|}{ Persons/Observation } & \multirow[b]{2}{*}{ Total } & \multicolumn{2}{|c|}{ Proportion Cloth Masks (\%) } & \multirow{2}{*}{ Observations } \\
\hline & $\operatorname{Avg} \pm$ Std. Dev & Range & & Avg \pm Std. Dev & Range & \\
\hline $\begin{array}{c}\text { Central Business } \\
\text { District }\end{array}$ & $38.3 \pm 11.7$ & $20-60$ & 804 & $36.89 \pm 8.18$ & $25.00-57.78$ & 21 \\
\hline Lavington & $69.4 \pm 37.4$ & $11-128$ & 833 & $30.70 \pm 7.45$ & $18.18-46.03$ & 12 \\
\hline \multirow[t]{2}{*}{ Special } & $52.5 \pm 31.8$ & $18-88$ & 207 & $26.97 \pm 6.91$ & $17.14-33.33$ & 4 \\
\hline & $49.92 \pm 28.16$ & $11-128$ & 1847 & $33.58 \pm 8.46$ & $17.14-57.78$ & 37 \\
\hline
\end{tabular}

Single-use surgical-type masks were the most common without exception, ranging in proportions from $42.2 \%$ to $82.86 \%$ among the individual observations. The wearing of single-use KN95 masks was observed, but only rarely (to a maximum of $3.8 \%$ during a single survey) (Table 2).

The numbers assessed on each survey ranged from 11 to 128 with substantial variation (the standard variation ranges from $30 \%$ to $60 \%$ of the mean value) (Table 1 ). Given the variation in sample size of the individual survey events, the data have been aggregated by location and area (Table 2).

The proportions of cloth masks worn in the two specialist stores (office supplies and hardware) is considerably less $(27.14 \%)$ than that of the other shops, which is statistically very significant for the CBD $\left(\chi^{2}=6.535 ; \mathrm{df}=1 ; p=0.0106\right)$ but not for Lavington $\left(\chi^{2}=2.456\right.$; $\mathrm{df}=1 ; p=0.1171)$. In addition, the proportions of cloth masks worn while walking on the street were lower than those observed in the shopping centers, both in the CBD $(25.71 \%)$ and in Lavington (26.67\%). Compared to proportions of cloth masks worn in the combined shops, the differences were statically very significant for the CBD $\left(\chi^{2}=4.79\right.$; $\mathrm{df}=1 ; p=0.0286)$ but again not for Lavington $\left(\chi^{2}=0.749 ; \mathrm{df}=1 ; p=0.3868\right)$.

\section{Discussion}

As at present there are no prior studies that quantified the choice of masks worn in Australia or by members of the Albury community, the baseline data compiled in this study (Tables 1 and 2), which show an average of 33.6\% cloth masks, cannot be readily compared with prior work. There are some local data on the relative proportions of types of masks encountered as litter in public spaces, which show that $95.8 \%$ of the masks were 
disposable, surgical type masks [36]. Given that fabric masks are reusable and washable, the proportion observed in that study reflects the community's rubbish discard behavior rather than actual usage of mask types.

Table 2. Aggregated results of the walk-trough surveys assessing mask use in Albury (NSW).

\begin{tabular}{|c|c|c|c|c|c|c|}
\hline \multirow{2}{*}{ Location } & \multirow{2}{*}{$\begin{array}{l}\text { Observations } \\
\text { (Visits) }\end{array}$} & \multicolumn{2}{|c|}{ Disposable } & \multirow{2}{*}{ Cloth/Fabric } & \multirow{2}{*}{ Total } & \multirow[b]{2}{*}{$\%$ Cloth } \\
\hline & & Surgical & KN95 & & & \\
\hline \multicolumn{7}{|l|}{ Central Business District } \\
\hline Aldi Supermarket & 4 & 63 & 4 & 39 & 106 & 36.79 \\
\hline Harris Farm Supermarket & 4 & 115 & 4 & 62 & 181 & 34.25 \\
\hline Myer Shopping Centre * & 3 & 181 & 0 & 93 & 274 & 33.94 \\
\hline \multirow[t]{2}{*}{ Westend Plaza ** } & 3 & 141 & 2 & 100 & 243 & 41.15 \\
\hline & all shops & 500 & 10 & 294 & 804 & 36.57 \\
\hline Lavington & & & & & & \\
\hline Centro Shopping Centre * & 3 & 427 & 4 & 216 & 647 & 33.38 \\
\hline \multirow[t]{2}{*}{ Coles Supermarket } & 2 & 129 & 0 & 57 & 186 & 30.65 \\
\hline & all shops & 556 & 4 & 273 & 833 & 32.77 \\
\hline \multicolumn{7}{|l|}{ Specialist Stores } \\
\hline OfficeWorks & 2 & 41 & 0 & 12 & 53 & 22.64 \\
\hline \multirow[t]{2}{*}{ Bunnings (Hardware) } & 2 & 111 & 1 & 45 & 157 & 28.66 \\
\hline & all shops & 152 & 1 & 57 & 210 & 27.14 \\
\hline \multicolumn{7}{|l|}{ Streets } \\
\hline CBD & 5 & 77 & 1 & 27 & 105 & 25.71 \\
\hline \multirow[t]{2}{*}{ Lavington } & 3 & 33 & 0 & 12 & 45 & 26.67 \\
\hline & all streets & 110 & 1 & 39 & 150 & 26.00 \\
\hline all Albury & & 1318 & 16 & 663 & 1997 & 34.00 \\
\hline
\end{tabular}

There are no Australian data that can be drawn on for comparison. On the international scale, a number of studies demonstrate usage between negligible and $92 \%$. In Japan, for example, the use of cloth face masks is almost non-existent, with hygiene mandates requiring the use of single-use face masks [49]. A Polish study, based on interviews, found that $46.2 \%$ of young adults used fabric masks, with women more likely to wear this type (48.6\% women vs. $36.5 \%$ men) [38]. A second study, also of Polish youths, found a similarly high level of fabric mask use $(47.7 \%)$, but without the previously noted pronounced gender bias (48.6\% women vs. $45.1 \%$ men) [37]. A survey of university students in Vietnam found that cloth masks were worn by $23.1 \%$ of the respondents [39]. A study in Iran, based on street observations, found that only $19.8 \%$ of pedestrians used cloth masks [44], while a similar street-based study in Bali observed a proportion of 39.5\% [40]. The extremes are represented by a survey in India, which yielded a proportion as low as $12.1 \%$ [42] and a survey of residents of Benin City (Nigeria) which found that $92 \%$ reported wearing cloth masks [41]. None of the studies comment on the fact whether a type of mask or its material were mandated by local health authorities.

Given the range of cultural backgrounds of the surveyed populations and the different nature of the survey methodologies used, these studies, while generally informative, are not directly comparable to the study reported here. The fact that one in three of observed adults wore washable and reusable fabric masks, despite the higher costs, suggests a considerable level of environmental awareness and commitment to sustainability. This dovetails with a high uptake of other environmental initiatives in the community, such as residential solar panels and rubbish segmentation into green waste, recycling and general waste (pers. obs.).

In the Australian setting, the directives and Public Health Orders issued by the state governments required the use of fitted masks, but did not specify their material (disposable, woven fabric, neoprene). Consequently, the choice of mask worn was solely defined by a user's personal choice. 
Given that this is an observational study, it is impossible to ascertain the user's motivations why they chose one type over the other, and to what extent issues of cost, convenience, comfort while wearing and environmental sustainability influenced their decision.

\subsection{Choice and Availability}

At the time of survey (August 2021) —disposable, surgical type masks were the most commonly worn kind of mask in Albury, at a ratio of almost 2:1. While this is primarily due to choice, it is not exclusively so, as it is also influenced by to opportunity. It was observed, for example, that some shopping venues, as well as schools and clubs, chose to provide free single-use surgical face masks to retain customers who forgot to bring a mask rather than to be forced to turn them away. Compared to single-use surgical masks, the KN95 masks, which at some stores were not more expensive than surgical masks, were observed only very rarely. Given their relative rarity, attention was paid to who was wearing them. The wearers tended to be overwhelmingly (with one exception) mature age and senior age males. Their attire did not suggest that they were building contractors who might wear such masks for professional reasons. It would appear that the KN95 masks were worn because of their better fit and superior filtering capabilities.

\subsection{Socio-Economic Factors}

As the rapid survey was designed to acquire quantitative data, the study is by necessity silent on factors regarding a user's motivations that would influence preference. While other studies have looked at mask awareness [50] and socio-economic factors [51] the present study is purely observational in nature and thus can only illuminate such aspects by proxy.

As the per-unit costs of the masks differ significantly, it can be posited that underlying socio-economic inequalities might influence the choice of masks. This can be tested, as the two areas with shopping centers and supermarkets that could be sampled (CBD and Lavington) differ in their clientele. Socio-economic indicators (based on the 2016 census) identify the suburb of Lavington as being low socio-economic as circumscribed by lower levels of educational attainment, with a higher rate of unemployment, a lower participation in any form of employment, a higher proportion of recent immigrants and non-English speakers [48]. A comparison of all sites (excluding streets) in the CBD with those in Lavington showed a higher proportion of cloth masks worn in the CBD $(36.50 \%$ vs. $32.66 \%)$, but this difference was statistically insignificant $\left(\chi^{2}=2.348, \mathrm{df}=1 ; p=0.1254\right)$. Given that shopping at specific supermarket chains is often based on brand-loyalty [52,53], a like-with-like comparison of the supermarkets in the CBD with those in Lavington also failed to show any statistically significant differences (Coles: $\chi^{2}=2.238$, $\mathrm{df}=1 ; p=0.1347$; Woolworths: $\left.\chi^{2}=0.401, \mathrm{df}=1 ; p=0.78402\right)$. Likewise, there was no significant difference in the proportions of cloth masks worn by people walking along the streets (which might suggest a lower income) between the CBD and Lavington $\left(\chi^{2}=0.015, \mathrm{df}=1 ; p=0.9026\right)$. This suggests that the pattern of mask use is independent of socio-economic influences and occurs in a uniform manner across Albury as a community.

\subsection{Implications}

This is not the venue to make definitive observations on the general efficacy of fabric masks vs. disposable surgical and KN95 masks [15-17] and the associated public health implications. Suffice to state, that the efficacy of fabric masks will be dependent on the nature and density of the fabric used, the presence of a wire to ensure tight fit around the nasal ridge, and the frequency and nature of cleaning (e.g., washing temperature, type of detergent) the masks are being subjected to. From a public health and hygiene perspective, this is obviously critical.

The observed high proportion of single-use masks has implications on municipal waste disposal as well as on environmental pollution on a macro level [36], and, after 
disintegration, on the level of microplastics [21,22]. Other observations noted that some masks ended up in creek lines or were washed into stormwater drains. Others, discarded on road side verges, were shredded by lawn mowing equipment, adding to microplastic dispersal [36]. From a resource management perspective, it seems advisable that public health agencies should encourage the uptake of high-quality cloth face masks, with insertable filter units.

\section{Conclusions}

This study is the first of its kind to provide quantitative baseline data for the nature of face mask use in an Australian community. Based on rapid walk-through surveys of shopping venues in a regional community of southern New South Wales, about two thirds of the public, irrespective of their socio-economic backgrounds, were observed to wear single use, surgical cloth masks. As a snapshot, they can be regarded as representative of a regional community in New South Wales, Australia's most populous state, with a liberal secular society of British tradition. To allow for greater generalization of the obtained results, it would be advantageous to repeat the survey in a purely rural and in a metropolitan community. Given the current situation in south-eastern Australia which is experiencing a high prevalence of the delta variant of COVID-19 associated with lockdowns of affected local government areas, such research has to await a future opportunity.

Funding: This research received no external funding.

Institutional Review Board Statement: Not applicable.

Informed Consent Statement: Not applicable.

Data Availability Statement: Not applicable.

Conflicts of Interest: The author declares no conflict of interest.

\section{References}

1. WHO. Naming the Coronavirus Disease (COVID-19) and the Virus that Causes It. Available online: https://www.who.int/ emergencies / diseases / novel-coronavirus-2019/technical-guidance/naming-the-coronavirus-disease-(covid-2019)-and-thevirus-that-causes-it (accessed on 10 August 2021).

2. Stadnytskyi, V.; Anfinrud, P.; Bax, A. Breathing, speaking, coughing or sneezing: What drives transmission of SARS-CoV-2? J. Intern. Med. 2021, 290, 1010-1027. [CrossRef] [PubMed]

3. Gorbunov, B. Aerosol particles generated by coughing and sneezing of a SARS-CoV-2 (COVID-19) host travel over $30 \mathrm{~m}$ distance. Aerosol Air Qual. Res. 2021, 21, 200468. [CrossRef]

4. Karaivanov, A.; Lu, S.E.; Shigeoka, H.; Chen, C.; Pamplona, S. Face masks, public policies and slowing the spread of COVID-19: Evidence from Canada. J. Health Econ. 2021, 78, 102475. [CrossRef]

5. Cherry, T.L.; James, A.G.; Murphy, J. The impact of public health messaging and personal experience on the acceptance of mask wearing during the COVID-19 pandemic. J. Econ. Behav. Organ. 2021, 187, 415-430. [CrossRef]

6. Guy, G.P., Jr.; Lee, F.C.; Sunshine, G.; McCord, R.; Howard-Williams, M.; Kompaniyets, L.; Dunphy, C.; Gakh, M.; Weber, R.; Sauber-Schatz, E. Association of state-issued mask mandates and allowing on-premises restaurant dining with county-level COVID-19 case and death growth rates-United States, 1 March-31 December, 2020. Morb. Mortal. Wkly. Rep. 2021, 70, 350. [CrossRef]

7. MacIntyre, C.R.; Nguyen, P.-Y.; Chughtai, A.A.; Trent, M.; Gerber, B.; Steinhofel, K.; Seale, H. Mask use, risk-mitigation behaviours and pandemic fatigue during the COVID-19 pandemic in five cities in Australia, the UK and USA: A cross-sectional survey. Int. J. Infect. Dis. 2021, 106, 199-207. [CrossRef]

8. Prata, J.C.; Silva, A.L.P.; Duarte, A.C.; Rocha-Santos, T. Disposable over Reusable Face Masks: Public Safety or Environmental Disaster? Environments 2021, 8, 31. [CrossRef]

9. Kournikakis, B.; Harding, R.K.; Tremblay, J.; Simpson, M. Comparison of protection factors for selected medical, industrial and military masks. Appl. Biosaf. 2000, 5, 12-18. [CrossRef]

10. Cherrie, J.W.; Apsley, A.; Cowie, H.; Steinle, S.; Mueller, W.; Lin, C.; Horwell, C.J.; Sleeuwenhoek, A.; Loh, M. Effectiveness of face masks used to protect Beijing residents against particulate air pollution. Occup. Environ. Med. 2018, 75, 446-452. [CrossRef]

11. Bubbico, L.; Mastrangelo, G.; Larese-Filon, F.; Basso, P.; Rigoli, R.; Maurelli, M.; Ferlito, S.; Capelli, M.; Gisabella, C.; Javanbakht, M.; et al. Community Use of Face Masks against the Spread of COVID-19. Int. J. Environ. Res. Public Health 2021, $18,3214$. [CrossRef] 
12. Coclite, D.; Napoletano, A.; Gianola, S.; Del Monaco, A.; D’Angelo, D.; Fauci, A.; Iacorossi, L.; Latina, R.; La Torre, G.; Mastroianni, C.M. Face mask use in the community for reducing the spread of COVID-19: A systematic review. Front. Med. 2020, 7, 594269. [CrossRef] [PubMed]

13. Spennemann, D.H.R. Collecting COVID-19 Ephemera: A Photographic Documentation of Examples from Regional Australia; Institute for Land, Water and Society Report 143; Institute for Land, Water and Society, Charles Sturt University: Albury, Australia, 2021.

14. Fretheim, A.; Elgersma, I.H.; Kristiansen, F.A.; Varmbo, C.R.; Olsbø, M.K.S.; Glover, I.H.S.; Flatø, M. The Effectiveness of Free Face Mask Distribution on Use of Face Masks. A Cluster Randomised Trial in Stovner District of Oslo, Norway. Int. J. Environ. Res. Public Health 2021, 18, 8971. [CrossRef]

15. Chughtai, A.A.; Seale, H.; Macintyre, C.R. Effectiveness of cloth masks for protection against severe acute respiratory syndrome coronavirus 2. Emerg. Infect. Dis. 2020, 26, e200948. [CrossRef] [PubMed]

16. Sharma, S.K.; Mishra, M.; Mudgal, S.K. Efficacy of cloth face mask in prevention of novel coronavirus infection transmission: A systematic review and meta-analysis. J. Educ. Health Promot. 2020, 9, 192. [CrossRef] [PubMed]

17. Pan, J.; Harb, C.; Leng, W.; Marr, L.C. Inward and outward effectiveness of cloth masks, a surgical mask, and a face shield. Aerosol Sci. Technol. 2021, 55, 718-733. [CrossRef]

18. Shaw, K.; Butcher, S.; Ko, J.; Zello, G.A.; Chilibeck, P.D. Wearing of Cloth or Disposable Surgical Face Masks has no Effect on Vigorous Exercise Performance in Healthy Individuals. Int. J. Environ. Res. Public Health 2020, 17, 8110. [CrossRef]

19. Scheid, J.L.; Lupien, S.P.; Ford, G.S.; West, S.L. Commentary: Physiological and Psychological Impact of Face Mask Usage during the COVID-19 Pandemic. Int. J. Environ. Res. Public Health 2020, 17, 6655. [CrossRef]

20. MacIntyre, C.R.; Dung, T.C.; Chughtai, A.A.; Seale, H.; Rahman, B. Contamination and washing of cloth masks and risk of infection among hospital health workers in Vietnam: A post hoc analysis of a randomised controlled trial. BMJ Open 2020, 10, e042045. [CrossRef]

21. Saliu, F.; Veronelli, M.; Raguso, C.; Barana, D.; Galli, P.; Lasagni, M. The release process of microfibers: From surgical face masks into the marine environment. Environ. Adv. 2021, 4, 100042. [CrossRef]

22. Wang, Z.; An, C.; Chen, X.; Lee, K.; Zhang, B.; Feng, Q. Disposable masks release microplastics to the aqueous environment with exacerbation by natural weathering. J. Hazard. Mater. 2021, 417, 126036. [CrossRef]

23. Allison, A.L.; Ambrose-Dempster, E.; Domenech Aparsi, T.; Bawn, M.; Casas Arredondo, M.; Chau, C.; Chandler, K.; Dobrijevic, D.; Hailes, H.C.; Lettieri, P. The impact and effectiveness of the general public wearing masks to reduce the spread of pandemics in the UK: A multidisciplinary comparison of single-use masks versus reusable face masks. UCL Open Environ. Prepr. $2020,3,1$. [CrossRef]

24. Cheng, F.-S.; Yen, Y.-F.; Lin, S.-Y.; Weng, S.-H.; Chou, Y.-C.; Chu, D.; Chen, C.-C.; Hu, H.-Y. Prevalence and Factors Associated with the Reuse of Mask during the COVID-19 Pandemic: A Nationwide Survey in Taiwan. Int. J. Environ. Res. Public Health 2021, 18, 8065. [CrossRef] [PubMed]

25. Lee, L.Y.-K.; Chan, I.C.-W.; Wong, O.P.-M.; Ng, Y.H.-Y.; Ng, C.K.-Y.; Chan, M.H.-W.; Ng, J.K.-C.; Koo, H.H.-T.; Lam, S.-T.; Chu, A.C.-W. Reuse of face masks among adults in Hong Kong during the COVID-19 pandemic. BMC Public Health 2021, 21, 1267. [CrossRef]

26. Pereira-Ávila, F.M.V.; Lam, S.C.; Góes, F.G.B.; Gir, E.; Pereira-Caldeira, N.M.V.; Teles, S.A.; Caetano, K.A.A.; Goulart, M.D.C.; Bazilio, T.R.; Silva, A.C.D.O. Factors associated with the use and reuse of face masks among Brazilian individuals during the COVID-19 pandemic. Rev. Lat.-Am. Enferm. 2020, 28, e3360. [CrossRef] [PubMed]

27. Zhang, J.; Heacock, H. Face Mask Reuse Behaviours in Canadians During the COVID-19 Pandemic. BCIT Environ. Public Health J. 2021. Available online: https://journals.bcit.ca/index.php/ehj/article/view/198 (accessed on 16 November 2021).

28. MHMR. Public Health (COVID-19 Greater Sydney) Order 2021. 2021; pp. 1-8. Available online: https:/ /legislation.nsw.gov.au/ file/Public\%20Health\%20(COVID-19\%20Greater\%20Sydney)\%20Order\%202021_210509.pdf (accessed on 16 November 2021).

29. MHMR. Public Health (COVID-19 Greater Sydney) Order (No 2) 2021. 2021; pp. 1-13. Available online: https: / / legislation.nsw. gov.au/file/Public\%20Health\%20(COVID-19\%20Greater\%20Sydney)\%20Order\%20(No\%202)\%202021_210626.pdf (accessed on 16 November 2021).

30. MHMR. Public Health (COVID-19 Temporary Movement and Gathering Restrictions) Order 2021. 2021; pp. 1-17. Available online: https:/ / www.industry.nsw.gov.au/_data/assets/pdf_file/0009/388989/Public-Health-COVID-19-TemporaryMovement-and-Gathering-Restrictions-Order-2021_210622.pdf (accessed on 16 November 2021).

31. MHMR. Public Health (COVID-19 Additional Restrictions for Delta Outbreak) Amendment (No 27) Order 2021. 2021; pp. 1-6. Available online: https:/ / legislation.nsw.gov.au/file/Public\%20Health\%20(COVID-19\%20Additional\%20Restrictions\%20for\% 20Delta\%20Outbreak)\%20Order\%202021_210731.pdf (accessed on 16 November 2021).

32. Spennemann, D.H.R. Curating the Contemporary: A case for national and local COVID-19 collections. Curator 2022, 65. accepted. [CrossRef]

33. Spennemann, D.H.R. COVID-19 on the ground: Heritage sites of a pandemic. Heritage 2021, 3, 2140-2162. [CrossRef]

34. Spennemann, D.H.R. Residential Architecture in a post-pandemic world: Implications of COVID-19 for new construction and for adapting heritage buildings. J. Green Build. 2021, 16, 199-215. [CrossRef]

35. Parker, M.; Spennemann, D.H.R. Anthropause on audio: The effects of COVID-19 pandemic on church bell ringing in New South Wales (Australia). J. Acoust. Soc. Am. 2020, 148, 3102-3106. [CrossRef]

36. Spennemann, D.H.R. COVID face masks: Policy shift results in increased littering. Sustainability 2021, 13, 9875. [CrossRef] 
37. Reszke, R.; Szepietowska, M.; Krajewski, P.K.; Matusiak, Ł.; Białynicki-Birula, R.; Szepietowski, J.C. Face Mask Usage among Young Polish People during the COVID-19 Epidemic-An Evolving Scenario. Healthcare 2021, 9, 638. [CrossRef] [PubMed]

38. Matusiak, Ł.; Szepietowska, M.; Krajewski, P.K.; Białynicki-Birula, R.; Szepietowski, J.C. The use of face masks during the COVID-19 pandemic in Poland: A survey study of 2315 young adults. Dermatol. Ther. 2020, 33, e13909. [CrossRef] [PubMed]

39. Duong, M.C.; Nguyen, H.T.; Duong, B.T. A Cross-Sectional Study of Knowledge, Attitude, and Practice Towards Face Mask Use Amid the COVID-19 Pandemic Amongst University Students in Vietnam. J. Community Health 2021, 46, 975-981. [CrossRef] [PubMed]

40. Siahaan, A.M.P.; Lubis, M.P.; Dalimunthe, D.A.; Nasution, M.R.; Lubis, H.P. Adherence to face mask and social distancing among residents in Medan during the COVID-19 pandemics. BAli Med. J. 2021, 10, 529-533.

41. Ukponahiusi, O.; Imafidon, K.A. Curbing the Spread of COVID-19: Face Mask Use among Nigerians. MedRxiv 2021. Available online: https://www.researchgate.net/publication/343350884_Curbing_the_Spread_of_Covid-19_Face_Mask_Use_among_ Nigerians (accessed on 10 October 2021).

42. Nazli, T.; Raheem, A.; Kishore, J. Perceptions and practices of the adult population in response to SARS-CoV-2 pandemic in India. Epidemiol. Int. 2020, 5, 10-16. [CrossRef]

43. Mejjad, N.; Cherif, E.K.; Rodero, A.; Krawczyk, D.A.; El Kharraz, J.; Moumen, A.; Laqbaqbi, M.; Fekri, A. Disposal Behavior of Used Masks during the COVID-19 Pandemic in the Moroccan Community: Potential Environmental Impact. Int. J. Environ. Res. Public Health 2021, 18, 4382. [CrossRef]

44. Rahimi, Z.; Shirali, G.A.; Araban, M.; javad Mohammadi, M.; Cheraghian, B. Mask use among pedestrians during the COVID-19 pandemic in Southwest Iran: An observational study on 10,440 people. BMC Public Health 2021, 21, 133. [CrossRef]

45. ABS. 2016 Census QuickStats. All People, Location on Census Night. Australia. Local Government Areas Albury (C) (LGA10050); Australian Bureau of Statistics: Canberra, Australia, 2016.

46. Spennemann, D.H.R. "No Entry into New South Wales": COVID-19 and the Historic and Contemporary Trajectories of the Effects of Border Closures on an Australian Cross-Border Community. Land 2021, 10, 610. [CrossRef]

47. MedCalc Software. MEDCALC. Comparison of Proportions Calculator. Available online: https://www.medcalc.org/calc/ comparison_of_proportions.php (accessed on 20 October 2018).

48. Id Profile. Albury City. Community Profile. Available online: https:// profile.id.com.au/albury (accessed on 21 August 2021).

49. Machida, M.; Nakamura, I.; Saito, R.; Nakaya, T.; Hanibuchi, T.; Takamiya, T.; Odagiri, Y.; Fukushima, N.; Kikuchi, H.; Amagasa, S.; et al. Incorrect Use of Face Masks during the Current COVID-19 Pandemic among the General Public in Japan. Int. J. Environ. Res. Public Health 2020, 17, 6484. [CrossRef]

50. Dwivedi, K.; Sharma, E.; Fatima, N. An empirical analysis on consumer's preferences of face mask during COVID-19 pandemic. Int. J. Home Sci. 2021, 7, 147-151.

51. Green, D.N.; Kozen, F.H.; Blumenkamp, C.K. Facemasking Behaviors, Preferences, and Attitudes Among Emerging Adults in the United States During the COVID-19 Pandemic: An Exploratory Study. Cloth. Text. Res. J. 2021, 39, 0887302X211006775. [CrossRef]

52. Knox, M. Supermarket Monsters: The Price of Coles and Woolworths' Dominance; Black Inc.: Collingwood, Australia, 2015; Volume 6.

53. Dwivedi, A.; Merrilees, B.; Miller, D.; Herington, C. Brand, value and relationship equities and loyalty-intentions in the Australian supermarket industry. J. Retail. Consum. Serv. 2012, 19, 526-536. [CrossRef] 